\author{
Julia Sowińska-Heim \\ ๑ https://orcid.org/0000-0003-3810-596X \\ Institute of History of Art, Faculty of Philosophy and History, University of Łódź \\ julia.sowinska@uni.lodz.pl
}

\title{
NARRATIVES ABOUT ARCHITECTURE
}

\begin{abstract}
Contemporary research on cities has shifted its focus from analysing formal features to aspects related to change and interaction dynamics. Seeing a city with its architecture as a system of mutual interactions and connections enables us to consider and analyse the relationships, processes, heterogeneous meanings and interpretative possibilities.

Thanks to this approach, we can explore diverse narratives focusing on architectural objects, shaped by, among others, changing social, political or economic conditions, as well as those resulting from the implementation of various conservation concepts.

The article presents these issues primarily with reference to creating contemporary narratives and, at the same time, reinterpreting architectural heritage important for the local community. It is a particularly interesting and current issue, given the fact that, in contrast to other fields of art, the analysis of architecture is still dominated by an approach which defines objects in a static, objective and finite way.
\end{abstract}

Keywords: architectural heritage, post-industrial architecture, architectural protection

Compared to other fields of art, a work of architecture is very strongly associated with the concept of durability and stability. Firmitas (durability), one of the three main characteristics of architecture, along with venustas (beauty) and utilitas (convenience), was included in the famous Vitruvian Triad. ${ }^{1}$ Wonderful architectural works of art somewhat fulfil our dream of gaining lasting eternal power and becoming a permanent part of the world history.

1 The suggested translations of the terms: firmitas, venustas and utilitas come from the book: Vitruvius, The Ten Book on Architecture, transl. M. H. Morgan, Harvard University Press, Cambridge 1914, p. 17. Utilitas is sometimes translated as utility, while firmitas is translated as stability. See, for example, Vitruvius, On Architecture, transl. R. Schofield, Penguin Classics, London 2009. 
At the same time, however, an analysis of architectural works requires taking into account the dynamics resulting from changing ways of perceiving the city and transformations concerning individual buildings or entire city quarters. According to Sigfried Giedion, history is not static, but dynamic. Thus, a work of art goes beyond holistic and finite approaches, and each generation discovers its new aspects. ${ }^{2}$

Contemporary complex processes connected with globalisation and its great influence on economic, social and cultural changes, as well as its direct and indirect impact on the urban tissue, have caused significant acceleration of the transformation pace. The changes are also visible in the discourse concerning the city and architecture, in which emphasis has been shifted from stylistic evaluations and the analysis of formal features towards aspects related to process dynamics, changes and interactions. More and more frequently, a city is perceived as a network of connections. ${ }^{3}$ From this perspective, contemporary agglomerations are not seen as a clearly defined area with defined spatial boundaries and dynamics of change, but as a complex mixture of places and flows with diverse relationships, activities and values which coexist, interact, connect, conflict, but also produce a creative synergy. ${ }^{4}$

One of the factors that have had significant influence on the contemporary view of the city as a system of mutual interactions and connections was research on the perception of the city conducted by Kevin Lynch, among others. The concept, which originated in 1960, assumed that architectural forms cannot be defined in an objective and permanent way, as their perception depends on external contexts and circumstances. ${ }^{5}$ In the 1960s, Henri Lefebvre wrote that a city has

2 Sigfried Giedion, Space, Time and Architecture: the Growth of a New Tradition, Harvard University Press, Cambridge-Massachusetts 1967, p. 5.

3 Networks understood as a characteristic feature of the contemporary society and culture, as well as their influence on city development were researched and described in an interesting way by Manuel Castellas. Manuel Castellas, The Rise of the Network Society, 2nd ed. Blackwell, Oxford 2000.

4 Patsy Healey, Urban Complexity and Spatial Strategies: Towards a Rational Planning for Our Times, Routledge, London-New York 2007, p. 1. As far as Polish researchers are concerned, a profound analysis of aspects related to the spatial and narrative-historical "eventualisation" of the city was conducted, among others, by Ewa Rewers, Zdarzenie w przestrzeni miejskiej, in: Formy estetyzacji przestrzeni publicznej, eds. J. S. Wojciechowski, A. Zeidler-Janiszewska, Instytut Kultury, Warszawa 1998, pp. 87-100. The author's deliberations on interpreting the city of events with the use of architectural discourse were based on the design and theoretical work of Bernard Tschumi.

Kevin Lynch, The Image of the City, M.I.T Press, Cambridge-London 1960. An analysis of 20th-century transformations leading to a departure from the analysis of architectural objects as static forms was carried out in: Lucyna Nyka, Od architektury cyrkulacji do urbanistycznych krajobrazów, Wydawnictwo Politechniki Gdańskiej, Gdańsk 2006. See also: Lucyna Nyka, W kierunku zmiennej metafory miasta - miejsca, zdarzenia, krajobrazy, in: Kazimierz Wejchert: teoria kompozycji urbanistycznej, ed. S. Gzell, Akapit-DTP, Warszawa 2003, pp. 52-61. 
a highly complex nature, so attempts to describe, analyse or synthesise it should never be considered exhaustive and finite. ${ }^{6}$

The issue has been interestingly analysed by, among others, Peter Bishop and Lesley Williams, who refer to the concept of »liquid modernity « of the Polish sociologist Zygmunt Bauman, ${ }^{7}$ as well as by Stephen Graham and Patsy Healey. They criticise object-centred theories based on Euclidean concepts, which perceive the city as a collection of static, normative and material forms - theories that do not take into account relationships and processes, various meanings and interpretative possibilities. ${ }^{8}$ Although the approach to the analysis of the city and its architecture has been changing since the turn of the 1960s and 1970, among others under the influence of postmodernism, poststructuralism and post-Fordism ${ }^{9}$, to name just a few movements, the city is still usually seen as a set of static objects.

This is particularly interesting in relation to issues and problems that focus on the protection of architectural heritage. ${ }^{10}$ In this case, there is a specific conflict between the desire to protect the material and meaningful status quo, and the changing social, cultural, political and economic context. By definition, architectural heritage is treated as "permanent properties $*{ }^{11}$ However, at the turn of the $21^{\text {st }}$ century, researchers reinforced their belief that cultural heritage could not be seen as unchangeable and static, and its redefinition through human actions had to be taken into account. ${ }^{12}$

This aspect is related to a phenomenon that has been clearly visible since the 1970s and strongly conditioned by social and cultural factors, i.e. the

6 Henri Lefebvre, Prawo do miasta, transl. Ewa Majewska, Łukasz Stanek, "Praktyka Teoretyczna”, 2012, no. 5, p. 190.

7 Peter Bishop, Lesley Williams, The Temporary City, Routledge, London-New York 2012. Cf. Zygmunt Bauman, Liquid Modernity, Polity Press, Cambridge 2000; Zygmunt Bauman, Kultura w płynnej nowoczesności, Agora, Warszawa 2011.

8 Stephen Graham, Patsy Healey, Relational Concepts of Space and Place: Issues for Planning Theory and Practice, "European Planning Studies", 1999, vol. 7, no 5, pp. 623-646.

9 Ibid., p. 624, 625.

10 These aspects are more widely discussed in: Julia Sowińska-Heim, Transformacje i redefinicje. Adaptacja dziedzictwa architektonicznego do nowej funkcji a zachowanie ciagłości historycznej miejsca, Wydawnictwo Uniwersytetu Łódzkiego, Łódź 2018.

11 Cf. Convention for the Protection of the Architectural Heritage of Europe, Grenada, 3 October 1985, art. 11.

12 The social aspect of architectural heritage protection began to attract more attention in the 1970s. Its importance was clearly highlighted in the Declaration of Amsterdam of 1975, as well as in the European Charter of the Architectural Heritage, proclaimed the same year, which emphasized the significance of the spiritual, cultural, social and economic values of the heritage and its role in maintaining harmonious social balance. European Charter of the Architectural Heritage, Council of Europe, October 1975, pt. 1-4; The Declaration of Amsterdam, Congress on the European Architectural Heritage, 21-25 October 1975. 
increasing importance of intangible heritage values and the conviction that they need to be equated with the tangible values of an object. This approach and perspective were particularly expressed in the Convention on the Value of Cultural Heritage for Society adopted in 2005, the so-called Faro Convention. ${ }^{13}$ What is important, the document emphasises that the whole society should participate in the continuous process of »defining cultural heritage.$^{14}$ Thus, the document stresses various and variable possibilities of perception and interpretation of the heritage, which are not described by clear and finite definitions. The Convention defines cultural heritage as a group of resources inherited from the past, which people identify, independently of ownership, as a reflection and expression of their constantly evolving values, beliefs, knowledge and traditions. ${ }^{15}$ Thus, emphasis has shifted from the previous significance of the tangible values of a building (which does not mean, of course, that they are now being negated) to the values related to a person (recipient and user), their perception of cultural heritage, as well as their relations and relationships arising with them. This significant change of perspective and way of thinking has even led to the conclusion that the main goal of the conservation of cultural heritage is human development and the quality of life. ${ }^{16}$ While, the Venice Charter, which established the foundations for $20^{\text {th }}$-century conservation theory just under forty years earlier (1964), defined the importance of protection and conservation of works of art as entirely and exclusively associated with the preservation of the material form and historical substance. ${ }^{17}$

In an approach that developing in the last decades of the $20^{\text {th }}$ century, according to which cultural heritage is not only a testimony and document of the past, but also as an important element of life of the contemporary society, a significant role is more and more often played not only by the previously dominant universalising trends, but also narratives emerging from small, local contexts. The Burra Charter, one of the earliest documents dealing with the issue of intangible values, stated that the values of cultural heritage are not universal or absolute, as they might be different for different social groups and individuals, as well as that cultural significance might change as a result of the continuous creation of the history of the given place. ${ }^{18}$ Together with

13 Council of Europe Framework Convention on the Value of Cultural Heritage for Society (Faro Convention), Faro, 27 October 2005.

14 Faro Convention, Preamble.

15 Faro Convention, art. 2.

16 Faro Convention, art. 1, pt. c.

17 International Charter for the conservation and Restoration of Monuments and Sites (The Venice Charter), 2nd International Congress of Architects and Technicians of Historic monuments, Venice 1964.

18 The Burra Charter was first adopted in 1979, then amended in 1981, 1988, 1999 and 2013. The Australia ICOMOS Charter for Places of Cultural Significance (The Burra Charter) with 
accentuating the social importance of heritage and intangible assets, emphasis is therefore shifted from the universal values of a site, which can be revealed by a proper investigation carried out by a small group of experts, to values important for the development and quality of human life ${ }^{19}$, including emotional values related to the perception of heritage as a symbol of cultural identity and continuity.

This means moving from the traditional approach, which sees values as constant, unchangeable and inherent to the object, to values that arise, as has already been mentioned, as a result of the interaction between the object and the historical, social or spatial context associated with it. Such an approach requires a fundamental modification of the way of thinking and a broader look at the issue by recognising that values are not only identified and defined by professionals analysing the object as a work of art or a past document, but also revealed through the analysis of factors such as cultural, social and economic change. ${ }^{20}$ The cultural context of each historical building must also be taken into account. ${ }^{21}$

At the end of the 1970s, it was indicated that protection and conservation should not only cover buildings of outstanding, universal, historical and aesthetic value $^{22}$, or ones that are significantly old, but also buildings and architectural complexes of local cultural and social importance. For example, in Lodz, one of the three largest Polish cities, whose history is closely linked to the development of the textile industry in the $19^{\text {th }}$ century, former red brick factories form an extremely important element of the city's cultural heritage, while such objects in Rome, with its ancient monuments, would be of lesser importance and would not create a social need for conservation and protection. ${ }^{23}$ As a result of such

Associates Guidelines and Code on the Ethics of Co-existence, International Council of Monuments and Sites 1999 r., art. 1.2 (with Explanatory Notes).

19 Faro Convention, pt. c.

20 Randall Mason, Assessing Values in Conservation Planning: Methodological Issues and Choices, in: Assessing the Values of Cultural Heritage: Research Report, ed. M. De la Torre, Getty Conservation Institute, Los Angeles 2002, p. 8.

21 ICOMOS Charter - Principles for the Analysis, Conservation and Structural Restoration of Architectural Heritage even states that since the value and authenticity of architectural heritage must be considered in the cultural context to which it belongs, it cannot therefore be based on constant and unchanging criteria. ICOMOS Charter - Principles for the Analysis, Conservation and Structural Restoration of Architectural Heritage, ICOMOS 14th General Assembly in Victoria Falls, Zimbabwe 2003, art. 1.2.

22 The Convention Concerning the Protection of the World Cultural and Natural Heritage of 1972, a crucial document for the development of research on cultural heritage, defined the concept of cultural heritage, indicating a distinctive feature of the "outstanding universal value of a work, complex or a historic site. Convention Concerning the Protection of the World Cultural and Natural Heritage, UNESCO 17th General Conference, Paris, 16 November 1972, art. 1.

23 This issue is interestingly pointed out by Bernard M. Feilden, Conservation of Historic Buildings, Architectural Press, Oxford 2003, p. 6. 
extended understanding of architectural heritage, the scope of protection has significantly increased, both by including a new type of heritage (e.g. industrial architecture) and by establishing a wider chronological (protection of newer sites) and geographical framework (primarily, becoming open towards non-European cultures). ${ }^{24}$

At the same time, in the 1970s, experts started to point out that the protection of historical cities meant not only the protection, preservation and restoration of architectural objects, but also ensuring their harmonious development and integration with the life of the modern society ${ }^{25}$. This perspective emphasises the value and importance of continuity primarily related to maintaining bonds between the community and the place. Continuity is connected with preserving the original function of the place or, if it is not possible, changing it. However, it must be used by the community connected with it. The community should also responsibly and actively participate in the process of heritage protection and conservation, based on local traditional knowledge and practice. Therefore, an important role is played by intangible values, but always in relation to tangible forms of heritage.

Consequently, in the last decades of the $20^{\text {th }}$ century, theoretical reflection also covered the issue of the status of grassroots changes (not supervised by specialists) introduced by users and resulting mainly from adaptive reuse. On the one hand, these changes are perceived as interferences distorting the original character of architectural heritage, while on the other hand, they are part of the history and life of the object, as well as a specific testimony to the confrontation of the original architectural concept with the changing social, historical or cultural situation. ${ }^{26}$ Authors such as Rodolfo Machado or Rodrigo Pérez de Arce, consider changes and modifications that arise over time as part of a natural process which should be given the same status as the original form. Machado compares it to a palimpsest and the process of overwriting successive meanings over time. He goes on to say that transformations are similar to underlining, erasing fragments, adding between the lines, commenting

24 Cf. François Choay, The Invention of the Historic Monument, Cambridge University Press, Cambridge 2001, p. 2, 4.

25 See, e.g. Charter for the Conservation of Historic towns and Urban Areas (Washington Charter), ICOMOS General Assembly in Washington, October 1987; Recommendation concerning the Safeguarding and Contemporary Role of Historic Areas, UNESCO 19th General Conference, Nairobi, 26 November 1976.

26 Issues concerning the status of spontaneous changes introduced by residents are analysed by, among others, Rodrigo Pérez de Arce, Urban Transformations and the Architecture of Additions, "Architectural Design", 1978, no. 4, pp. 237-266; Fred Scott, On Altering Architecture, Routledge, London-New York 2007; Aldo Rossi, The Architecture of the City, The MIT Press, Cambridge-Massachusetts-London 1982. 
or specifying, and constitute a search for a new form for an old story. ${ }^{27}$ Fred Scott asks which buildings are more authentic: those that were spontaneously adapted by the inhabitants or those restored to their original form as a result of conservation work. ${ }^{28}$ With regard to contemporary interventions, this approach raises considerable doubts and controversies, but its assessment seems less clear from a historical perspective. A good example may be the historical centre of Split with the remains of the ancient palace of Emperor Diocletian from the turn of the 4th century, the form of which, together with subsequent interventions gradually introduced in various periods, reflects the occurring changes and current needs. The ruins of the palace, remaining an important testimony to the past and constituting the core of the city, were at the same time integrated and woven into its historical, social and cultural transformations. ${ }^{29}$ These transformations mainly resulted from spontaneous actions performed by the inhabitants.

A special role in the process of integrating objects from the past with the current life of the society and the city belongs to the domain of adaptive reuse of architectural heritage. It leads to the reinterpretation of architectural heritage and creation of a contemporary narrative. The process of adaptive reuse entails specific modernisation of the historical object by a conscious addition of the current aesthetic value and cultural meaning. The past remains a value, but not the only one, because the contemporary dialogue between the history of the place, building or architectural complex and its current importance leads to the creation of a new vital layer of significance. ${ }^{30}$

27 Rodolfo Machado, Towards a Theory of Remodelling. Old Buildings as Palimpsest, "Progressive Architecture", 1976, no. 11, pp. 46-49.

28 Fred Scott, On Altering..., pp. 20-43.

29 The issue of grassroots social activities as a catalyst for the regeneration of architectural heritage was analysed in the article: Bie Plevouts, Julia Sowińska-Heim, Community initiatives as a catalyst for regeneration of heritage sites: Vernacular transformation and its influence on the formal adaptive reuse practice, "Cities", 2018, vol. 78, pp. 128-139. An analysis of the living heritage approach is undertaken by Ioannis Poulios. Ioannis Poulios Discussing Strategy in heritage conservation: Living Heritage Approach as an example of Strategic Innovation, "Journal of Cultural Heritage Management and Sustainable Development", 2014, vol. 4, pp. $16-34$.

30 The reasons why the phenomenon of modern architectural interventions in historical buildings has currently intensified can be related to social, cultural, local or global identity issues playing a special role at the turn of the 21st century; cf. Ewa Rewers, Niepewny urok tożsamości, [in:] Kultura wobec kręgów tożsamości. Materiaty konferencji przedkongresowej, Poznań 19-21 października 2000, eds. T. Kostyrko, T. Zgółka, Poznań-Wrocław 2000, pp. 109-119; Julia Sowińska-Heim, Transformacje i redefinicje. Adaptacja dziedzictwa architektonicznego do nowej funkcji a zachowanie ciagtości historycznej miejsca, Wydawnictwo Uniwersytetu Łódzkiego, Łódź 2018. 
The very loss of the original function creates new contexts and meanings. Recalling Pierre Nora's views, including treating the transition from »milieux de mémoire « to »lieux de mémoire $\ll^{31}$ as breaking the cultural framework of meanings and social contexts, Aleida Assmann stresses that the loss of context causes specific auratisation of relics at the site of commemoration. ${ }^{32}$ She compares this process with the aestheticization of everyday objects which, after being placed at a museum and deprived of their functional context and meaning, become similar to works of art characterised by being function-free and contextless. Quoting Krzysztof Pomian, she recalls an example of a factory that has lost its initial industrial function and become a relic of the past. As Pomian notes, such a factory evokes and provokes various assessments, gestures and attitudes towards represented history. It can be seen as a sign of progress and development, or a symbol of the exploitation of workers and class struggle. Transferred into the semiotic cycle, it becomes a tangible carrier of meanings ${ }^{33}$, an artefact with a cultural interpretation. At the same time, the introduction of a different function adapted to current needs gives it new, contemporary meaning.

One way of building dialogue with the past consists in striving for the symbiotic coexistence of old and new meanings and forms. The introduced changes and transformations related to the new function become part of the existing solutions, without blurring the original character of places or attributes related to their original purpose. The story of the past smoothly incorporates the next stage of a place's history associated with its gradual transformation. "New life" enters the old spaces, creating unusual connections. Elements of the physical structure, which once served a specific function, can be reused in an unconventional way. The change, however, appears to be a natural process of transformation which fills desolate structures and spaces with a new function, rather than a permanent, single architectural intervention. The intertwined present and past emphasise the historical and social continuity of the place.

31 As for the notions of »milieux de mémoire« and »lieux de mémoire« in Pierre Nora’s concept, see: Pierre Nora, Czas pamięci, transl. W. Dłuski, "Res Publica Nowa", 2001, no. 7, pp. 37-43; Pierre Nora, Między pamięcia a historiq: les lieux de mémoire, "Tytuł roboczy: archiwum”, transl. Paweł Mościcki, 2009, no. 2, pp. 4-12.

32 Aleida Assmann, Między historia a pamięcia. Antologia, ed. Magdalena Saryusz-Wolska, Wydawnictwo Uniwersytetu Warszawskiego, Warszawa 2013, p. 178. The author analyses these issues primarily in relation to traumatic places.

33 Krzysztof Pomian, Museum und kulturelles Erbe [in:] Gottfried Korff, Martin Roth, Das historische Museum. Labor - Schaubühne - Identitätsfabrik, Campus Verlag GmbH, Frankfurt 1990, p. 42. As cited in: Aleida Assmann, Między historiq a pamięciq..., p. 179; cf. Krzysztof Pomian, Jak uprawiać historię kultury, "Przegląd Historyczny", 1995, vol. 86, issue 1, pp. $1-13$. 
A climbing wall using former structures, a bar among industrial machines, a concert hall and theatre hall at a steam treatment plant, or a diving pool in a disused mine building ${ }^{34}$ are examples of a special kind of coexistence - they enable us to commune with the past outside museum space. Such surprising juxtapositions of the original, unadorned, patina-covered form and the new function undoubtedly attract our attention and may become a kind of a tourist attraction. However, they first and foremost offer us the opportunity to discover and experience places which constitute a testimony of the past.

Such an approach is visible, among others, in the concept of adaptive reuse and regeneration of post-industrial areas in the German cities of Duisburg, Saarbrücken or Essen. Newly created areas combine the industrial past with sustainability and ecology. The introduction of diverse functions related to leisure, cultural and artistic activities, but also commercial undertakings does not involve any fundamental interference with the existing form, which is why contemporary life seems to be taking place among relics of the past, creating ambiguous and unobvious spaces. The exploration of labyrinths formed by old structures is an educational experience and, at the same time, the act of penetrating old structures and discovering surprising picturesque perspectives helps us satisfy our contemporary needs.

The Landschaftspark Duisburg-Nord in the Ruhr, created on the premises of the former August Thyssen ironworks from the turn of the $20^{\text {th }}$ century, has been transformed into a new type of a landscape park that meets the expectations of people of all ages, where visitors can both climb the viewing platform on top of one of the blast furnaces and watch a high-class cultural show. ${ }^{35}$ However, due to the historical authenticity of the preserved objects and machines, the construction is far from being artificial or trivial. While maintaining respect for its own history, the Landschaftspark is at the same time a living space open to the public.

Nowadays, vegetation surrounding and growing on the empty industrial buildings also constitutes an important part of the complex. The objects are becoming elements of the landscape, intriguing structures that influence its industrial aesthetics. They create a picturesque view resembling mysterious

34 Examples of such solutions can be found in Duisburg, Essen and Beringen.

35 The ironworks operated until 1985, while the functional transformation of the site started in 1989. The project was launched in 1991 and, already in 1994, the first part of the construction was put into operation. The whole area covers 230 ha. The Duisburg-Nord adaptation is part of a larger project, the International Building Exhibition Emscher Park (IBA), launched in 1990, which aims at the functional, social, economic and ecological renewal of the Ruhr. The IBA Emscher Park comprises as many as 117 projects run by 17 cities. The former Zollverein mine in Essen is also one of the most important flagship projects within the IBA Emscher Park, together with Duisburg-Nord and Mont-Cenis in Herne. 
ruins in a romantic garden. ${ }^{36}$ The factory, whose operation was associated with significant environmental pollution, has been transformed into a quiet green space and a meeting place where people can rest from the urban bustle.

The degradation (passing, disintegration) of post-industrial objects combined with the introduction of vegetation (regeneration, rebirth) provokes a search for broader references and attempts to read their allegories. ${ }^{37}$ An important aspect here is a reflection on the current role and interpretation of "ruins". Analysing the desire typical of the turn of the $21^{\text {st }}$ century, to preserve and transform post-industrial complexes »authentic ruins of modernity«, Andreas Huyssen points out that its main cause was nostalgia, a kind of longing for a bygone period that carried the promise of a different, better future characteristic of modern times. ${ }^{38}$

However, if we look at the complex in Duisburg, it seems that continuity and change perceived as a natural process are mainly emphasized as its dominant features. Peter Latz, the chief architect in charge of the complex transformation, points out that the conceptual basis of the undertaking was a method of work based on adaptation and interpretation, leading to "a metamorphosis of industrial structures without destroying them ${ }^{39}{ }^{39}$ The project is primarily

36 The metaphorical meaning of the a post-industrial »ruin « is referred to, among others things, by: Ann Storm, Post-Industrial Landscape Scars, Palgrave Macmillan, New York 2014, p. 100; Kerstin Barndt, "Memory Traces of an Abandoned of Futures". Industrial Ruins in the Postindustrial Landscapes of Germany, in: Ruins of Modernity, ed. J. Hell, Andreas Schönle, Duke University Press, Durham-London 2010, p. 270. A combination of post-industrial structures and greenery is also present in other projects, such as the High Line in New York, based on the transformation of a railway line devoid of its original function into a park (according to the project design of James Corner Field Operations and Diller Scofidio + Renfro). However, in the case of Duisburg, the way of building relationships between arteifacts from the past and the natural landscape in the case of Duisburg creates special connections and connotations.

37 In her search for a broader context, Kerstin Barndt refers to the opinions of, among others, Walter Benjamin and Reinhart Koselleck, starting her deliberations with the concept of Koselleck's »levels of time " and Benjamin's statement that "allegories are, in the realm of thoughts, what ruins are in the realm of things «. She associates the transformation of postindustrial space into a relaxation spot and the resulting surprising and unexpected combinations with the postmodern concept. She also embeds the pursuit of preserving post-industrial objects in the context of German history and changes taking place after 1989. Kerstin Barndt, "Memory Traces of an Abandoned of Futures..., pp. 270-291; cf. Walter Benjamin, Źródło dramatu żałobnego w Niemczech, transl. Andrzej Kopacki, Sic!, Warszawa 2013; Reinhart Koselleck, Warstwy czasu. Studia z metahistorii, transl. K. Krzemieniowa, J. Merecki, Oficyna Naukowa, Warszawa 2012.

38 Andreas Huyssen, Nostalgia for Ruins, “Grey Room”, 2006, no. 23, pp. 6-21. See also: Ruins of Modernity... In his analysis of the post-industrial landscape of Detroit, George Steinmetz also refers to the meaning of "ruins", nostalgia and Fordism. George Steinmetz, Colonial Melancholy and Fordist Nostalgia. The Ruinscapes of Namibia and Detroit, in: Ruins of Modernity..., pp. 294-320.

39 As cited in: Kerstin Barndt, "Memory Traces of an Abandoned of Futures..., p. 272. 
aimed at shaping a coherent, but at the same time unobvious and ambiguous landscape, which becomes an expression of creative and artistic activity. Landschaftspark Duisburg-Nord is not only one of the most important examples of adaptive reuse, but also a design that has had a significant impact on landscape architecture as a discipline. ${ }^{40}$ Even though the principles underlying its creation have been derived from the history of garden and park design, as well as art, architecture and urban planning theories, they first and foremost form a new, coherent whole. ${ }^{41}$ Austere, heavy constructions and industrial structures have undergone a metamorphosis and become an intergral part of the park. As architect Peter Latz points out, the initial fear of pollution and contamination of the site is replaced with calm acceptance of old industrial buildings. People are happy to meet at the "places where the trees in blossom interweave with the bizarre framework of the blast furnaces and the windheaters to a fantastic image «. ${ }^{42}$

The post-industrial area, where previous generations used to work hard, has now been transformed and accepted by the inhabitants as good space for leisure activities, walks, social gatherings, children's play or ball games. The past and the present, though completely different, blend and intertwine seamlessly to create a story about the place. The maintaned continuity does not mean stagnation. With time, the post-industrial artefact will be dominated by vegetation. The change is not a single act, but a process of gradual transformation and building a new story in the symbiosis. ${ }^{43}$

40 As a result of social and economic changes, it was necessary to rethink the concept of a "park", especially in the context of post-industrial areas. The Duisburg project inspired, among others, Kongjian Yu, a Chinese landscape architect, to design the Zhong-shan Shipyard Park (2000) in one of the largest post-industrial areas in China. See Kongjian Yu, The Aesthetic of the Rustic, in: Learning from Duisburg-Nord, ed. U. Weilacher, Technische Universität, München 2009, p. 78, 79. Interestingly, in 2015, "The Guardian” included DuisburgNord on the list of the most important parks, along with, for example, the Bobola gardens in Florence and the Güell Park in Barcelona. See Rowan Moor, The 10 Best Parks, "The Guardian”, 2015, https://www.theguardian.com/culture/2015/aug/07/10-best-parks-urbangreen-spaces-high-line-new-york-hampstead-london-park-guell-barcelona (28.07.2020).

41 Above all, Udo Weilacher points out, above all, the influence of structuralists such as Herman Hertzberger, who believed that creating new things is only possible through a different interpretation of existing images and designing polyvalent spaces and structures, while recognising that attempts to create "sterile" designs starting from with a clean, white sheet of paper have negative consequences. He also refers to Bernard Lassus and Lucius Burckhardt, whose postulate on the principle of minimum intervention had already influenced the theory of landscape architecture in Germany in the 1980s. Udo Weilacher, Learning from DuisburgNord, 2009, https://www.researchgate.net/ publication/272166777 (access: 12.06.2018).

42 NODH. Duisburg-Nord - Blast Furnace Park, https://www.latzundpartner.de/en/projekte/ postindustrielle-landschaften/duisburg-nord-hochofenpark/ (26.07.2020). Cf. Peter Latz, RUST RED - The Landscape Park Duisburg-Nord, Hirmer Publishers, München 2016.

43 Peter Latz assumes further natural development of the garden and changes resulting from progressing rust, and further erosion of the giant metal structures. See NODH. DuisburgNord...; Peter Latz, Landscape Park Duisburg-Nord..., pp. 150-159. 


\section{BIBLIOGRAPHY:}

Assmann Aleida (2013) Między historiq a pamięciq. Antologia, M. Sariusz-Wolska ed., Warszawa: Wydawnictwo Uniwersytetu Warszawskiego.

Barndt Kerstin (2010) "Memory Traces of an Abandoned of Futures". Industrial Ruins in the Postindustrial Landscapes of Germany, [in:] J. Hell, A. Schönle eds., Ruins of Modernity, DurhamLondon: Duke University Press, pp. 270-293.

Bauman Zygmunt (2000) Liquid Modernity, Cambridge: Polity Press.

Bauman Zygmunt, Kultura w płynnej nowoczesności, Agora, Warszawa 2011.

Benjamin Walter (2013) Źródto dramatu żałobnego w Niemczech, transl. Andrzej Kopacki, Warszawa: Sic!.

Bishop Peter, Williams Lesley (2012) The Tempory City, London-New York: Routledge.

Castellas Manuel (2001) The Invention of the Historic Monument, Cambridge: Cambridge University Press.

Congress on the European Architectural Heritage (1975) The Declaration of Amsterdam, Amsterdam.

Council of Europe (1975) European Charter of the Architectural Heritage.

Council of Europe (1985) Conversation for the Protection of the Architectural Heritage of Europe, Grenada.

Council of Europe (2005) Framework Convention on the Value of Cultural Heritage Society (Faro Convention), Faro.

Feilden Bernard M. (2003) Conversation of Historic Buildings, Oxford: Architectural Press.

Giedion Sigfried (1967) Space, Time and Architejture: the Growth of a New Tradition, CambridgeMassachusetts: Harvard University Press.

Graham Stephen, Healy Patsy (1999) Relational Concepts of Space and Place: Issues for Planning Theory and Practice, "European Planning Studies", vol. 7, no. 5, pp.623-646.

Healy Patsy (2007) Urban Complexity and Spatial Strategies: Towards a Rational Planning for Our Times, London-New York: Routledge.

Huyssen Andreas (2006) Nostalgia for Ruins, “Grey Room”, no. 23, pp. 6-21.

International Council of Monument and Sites (1964) International Charter for the conservation and Restoration of Monuments and Sites (The Venice Charter), Venise.

International Council of Monument and Sites (1987) Charter for the Conservation of Historic towns and Urban Areas (Washington Charter), Washington. 
International Council of Monument and Sites (1999) The Australia ICOMOS Charter for Places of Cultural Significance (The Burra Charter) with Associates Guidelines and Code on the Ethics of Co-existence.

International Council of Monument and Sites (2003) ICOMOS Charter - Principles for the Analysis, Conservation and Structural Restoration of Architectural Heritage, Zimbabwe.

Koselleck Reinhart (2012) Warstwy czasu. Studia z metahistorii, transl. Krystyna Krzemieniowa, Jarosław Merecki, Warszawa: Oficyna Naukowa.

Latz Peter (2016) RUST RED - The Landscape Park Duisburg-Nord, München: Hirmer Publishers.

Lefebvre Henri (2012) Prawo do miasta, transl. E. Majewska, Ł. Stanek, "Praktyka Teoretyczna", no. 5 , pp. 183-197.

Lynch Kevin (1960) The Image of the City, Cambridge-London: M.I.T Press.

Machado Rodolfo (1976) Towards a Theory of Remodelling. Old Buildings as Palimpsest, "Progressive Architecture", no. 11, pp. 46-49.

Mason Randall (2002) Assessing Values in Conservation Planning: Methodological Issues and Choices, [in:] M. De la Torre ed., Assessing the Values of Cultural Heritage: Research Report, Los Angeles: Getty Conservation Institute, pp. 5-30.

Moor Rowan (2015) The 10 Best Parks, "The Guardian", https://www.theguardian.com/culture/ 2015/aug/07/10-best-parks-urban-green-space-high-line-new-york-hampstead-london-park-guellbarcelona (access: 28.07.2020).

NODH. Duisburg-Nord - Blast Furnace Park, https://www.latzundpartner.de/en/projekte/postindustrielle-landschaften/duisburg-nord-hochofenpark/ (26.07.2020).

Nora Pierre (2001) Czas pamięci, transl. W. Dłuski, “Res Publica Nowa”, no. 7, pp. 37-43.

Nora Pierre (2009) Między pamięciq a historiq: les lieux de mémoire, "Tytuł roboczy: archiwum”, transl. Paweł Mościcki, no. 2, pp. 4-12.

Nyka Lucyna (2003) W kierunku zmiennej metafory miasta - miejsca, zdarzenia, krajobrazy [in:] S. Gzell ed., Kazimierz Wejchert: teoria kompozycji urbanistycznej, Warszawa: Akapit-DTP, pp. $52-61$.

Nyka Lucyna (2006) Od architektury cyrkulacji do urbanistycznych krajobrazów, Gdańsk: Wydawnictwo Politechniki Gdańskiej.

Pérez de Arce Rodrigo (1978) Urban Transformations and the Architecture of Additions, "Architectural Design”, no. 4, pp. 237-266.

Plevouts Bie, Sowińska-Heim Julia (2018) Community initiatives as a catalyst for regeneration of heritage sites: Vernacular transformation and its influence on the formal adaptive reuse practice, “Cities”, vol. 78, pp. 128-139. 
Pomian Krzysztof (1995) Jak uprawiać historię kultury, "Przegląd Historyczny”, vol. 86, issue 1, pp. 1-13.

Poulios Ioannis (2014) Discussing Strategy in heritage conservation: Living Heritage Approach as an example of Strategic Innovation, "Journal of Cultural Heritage Management and Sustainable Development", vol. 4 pp. 16-34.

Rewers Ewa (1998) Zdarzenie w przestrzeni miejskiej, [in:] J. S. Wojciechowski, A. Zeidler-Janiszewska, eds., Formy estetyzacji przestrzeni publicznej, Warszawa: Instytut Kultury, pp. 87-100.

Rewers Ewa (2000) Niepewny urok tożsamości, [in:] T. Kostyrko, T. Zgółka eds., Kultura wobec kręgów tożsamości. Materiaty konferencji przedkongresowej, Poznań 19-21 października 2000, Poznań-Wrocław 2000, pp. 109-119;

Rossi Aldo (1982) The Architecture of the City, Cambridge-Massachusetts-London: The MIT Press.

Scott Fred (2007) On Altering Architecture, London-New York: Routledge.

Sowińska-Heim Julia (2018) Transformacje i redefinicje. Adaptacja dziedzictwa architektonicznego do nowej funkcji a zachowanie ciagłości historycznej miejsca, Łódź: Wydawnictwo Uniwersytetu Łódzkiego.

Steinmetz George (2010), Colonial Melancholy and Fordist Nostalgia. The Ruinscapes of Namibia and Detroit, [in:] J. Hell, A. Schönle eds., Ruins of Modernity, Durham-London: Duke University Press, pp. 294-320.

Storm Ann (2014) Post-Industrial Landscape Scars, New York: Palgrave Macmillan.

UNESCO (1972) Convention Concerning the Protection of the World Cultural and Natural Heritage, Paris.

UNESCO (1976) Recommendation concerning the Safeguarding and Contemporary Role of Historic Areas, Nairobi.

Vitruvius (1914) The Ten Book on Architecture, transl. M. H. Morgan, Cambridge: Harvard University Press.

Vitruvius (2009) On Architecture, transl. R. Schofield, London: Penguin Classics.

Weilacher Udo (2009) Learning from Duisburg-Nord, https://www.researchgate.net/ publication/272166777 (access: 12.06.2018).

Yu Kongjian (2009) The Aesthetic of the Rustic, [in:] U. Weilacher ed., Learning from DuisburgNord, München: Technische Universität, pp. 78-79. 


\section{NARRACJE O ARCHITEKTURZE (streszczenie)}

We współczesnych badaniach dotyczących miasta następuje przesunięcie akcentu z analizy cech formalnych w kierunku aspektów związanych z dynamiką zachodzących zmian oraz interakcji. Spojrzenie na miasto i jego architekturę jako układ wzajemnych oddziaływań i powiązań pozwala na uwzględnienie i analizę zachodzących relacji oraz procesów, heterogenicznych znaczeń i możliwości interpretacyjnych.

Podejście to umożliwia badanie zróżnicowanych narracji, zogniskowanych wokół obiektów architektonicznych, a kształtowanych m.in. przez zmienne warunki społeczne, polityczne, czy gospodarcze, jak i te wynikające z realizowania różnorodnych koncepcji konserwatorskich.

W artykule zagadnienia te zaprezentowane zostały przede wszystkim na przykładzie tworzenia współczesnych narracji i jednocześnie reinterpretacji dotyczących ważnego dla lokalnej społeczności dziedzictwa architektonicznego.

Problematyka ta jest tym bardziej interesująca i aktualna, że w przeciwieństwie do innych dziedzin sztuki, w analizach poświęconych architekturze nadal dominuje podejście według, którego możliwe jest definiowanie obiektów w sposób statyczny, obiektywny i wyczerpujący.

Słowa kluczowe: dziedzictwo architektoniczne, architektura postindustrialna, ochrona architektury

Julia Sowińska-Heim - art historian, Assistant Professor at the Department of Art History at the University of Lodz. Currently, she is focusing her research interest mainly on adaptive reuse of architectural heritage. She is a member of the international expert committee of the Belgian Research Foundation and vice president of the standing commission on Łódź centre of the Revival Committee. In the academic 2017/2018 she was a voluntary research assistant at Universiteit Hasselt. She carried out the research, among others during the internship and the individual grant (Special Research Fund) awarded by the Universiteit Hasselt in Belgian.

Author and co-author of 50 publications, among others an author of a book Tansformacje i redefinicje. Adaptacja dziedzictwa architektonicznego do nowej funkcji a zachowanie ciagłości historycznej miejsca (2018) and co-author of an article Community Initiatives as a Catalyst for Regeneration of Heritage Sites: Vernacular Transformation and its Influence on the Formal Adaptive Reuse Practice (2018), published in the international Elsevier's journal "Cities" (WoS publication). 